\title{
Papaya seedlings irrigation with saline water in soil with bovine biofertilizer
}

\author{
Antonio J. de Lima-Neto ${ }^{1 *}$, Lourival F. Cavalcante ${ }^{2}$, Francisco de 0. Mesquita ${ }^{3}$, \\ Antônio G. de L. Souto ${ }^{1}$, Gaudêncio P. dos Santos ${ }^{2}$, Juliana Z. dos Santos², \\ and Evandro F. de Mesquita ${ }^{4}$
}

\section{ABSTRACT}

Water used for irrigation in semiarid regions of the world is not always of good quality, and may contain salts levels that inhibit plants growth. This study was conducted to evaluate the growth of papaya (Carica papaya L.) 'Golden' seedlings irrigated with saline water in soil with and without bovine biofertilizer produced by anaerobic fermentation of a mixture of fresh bovine manure and water. The experiment was carried out in Areia County, Paraiba State, Brazil. Treatments were distributed in randomized blocks using a factorial design $5 \times 2$ relative to five salinity levels in irrigation water of $0.5,1.0,2.0,3.0$ and $4.0 \mathrm{dS} \mathrm{m}^{-1}$ in soil with and without bovine biofertilizer, corresponding to $10 \%$ of the substrate volume. At $90 \mathrm{~d}$ after emergence (DAE), both the electrical conductivity (EC) in soil saturation extract, biometric growth and DM production of papaya seedlings were evaluated. Increased salinity from 0.5 to $4.0 \mathrm{dS} \mathrm{m}^{-1}$ raised, within $90 \mathrm{DAE}$, soil EC of saturation extract (ECse) from 1.19 to $3.95 \mathrm{dS} \mathrm{m}^{-1}$ and from 1.23 to $3.63 \mathrm{dS} \mathrm{m}^{-1}$ in treatments with and without bovine biofertilizer, respectively. Also, the increase in water salinity from $0.5 \mathrm{dS} \mathrm{m}^{-1}$ to the estimated maximum values ranging from 1.46 to $2.13 \mathrm{dS} \mathrm{m}^{-1}$ stimulated seedling height to 11.42 and $18.72 \mathrm{~cm}$ in soil with and without bovine biofertilizer, respectively. Higher salinity levels in irrigation water increased soil salinity levels to values that inhibited both growth and quality of papaya seedlings, but with less severity when treated with bovine biofertilizer.

Key words: Carica papaya, growth, humic substances, organic fertilization, salt stress.

${ }^{1}$ Universidade Federal de Viçosa (UFV), Departamento de Fitotecnia, Av. Peter Henry Rolfs, s/n, Centro, 36570-000, Viçosa-MG, Brasil. "Corresponding author (limanetoagro@ hotmail.com).

${ }^{2}$ Universidade Federal da Paraíba (UFPB), Centro de Ciências Agrárias (CCA), Rodovia PB-079, 58397-000, Areia-PB, Brasil.

${ }^{3}$ Universidade Federal Rural do Semi-Árido (UFERSA), Departamento de Ciências Ambientais e Tecnológicas, Av. Francisco Mota, No 572, Costa e Silva, 59625-900, Mossoró-RN, Brasil.

${ }^{4}$ Universidade Estadual da Paraíba (UEPB), Centro de Ciências Humanas e Agrárias, Sítio Cajueiro, Zona rural, 58884-000, Catolé do Rocha-PB, Brasil.

Received: 16 November 2015.

Accepted: 12 March 2016.

doi:10.4067/S0718-58392016000200014

\section{INTRODUCTION}

Papaya (Carica papaya L.) is one of the most cultivated and consumed fruits, both in tropical and subtropical regions. It was discovered by the Spaniards in the region between southern Mexico and northern Nicaragua, and is currently distributed in many tropical regions of the world (Serrano and Cattaneo, 2010).

Brazil is the world's second largest papaya producer after India. Its Northeast region contributes significantly to the national production. Bahia, Espírito Santo, Minas Gerais, Ceará, and Rio Grande do Norte are the major producer states (Anuário Brasileiro de Fruticultura, 2015). Due to environmental conditions and rainfall irregularity in this region, the use of irrigation in papaya cultivation can promote increased productivity, making it an economically viable crop (Santos et al., 2008).

The quality of seedlings used in the formation of an orchard defines the productive potential of the crop, requiring high quality and strong seedlings with good nutritional status. Under semiarid conditions, due to salinity problems that compromise seedling quality, studies in the formation phase, i.e., initial plant growth, are needed to identify tolerant materials (Sá et al., 2013).

Papaya is moderately tolerant to soil salinity. Growth inhibition and crop productive capacity does not occur when cultivated in soils with a saturation extract electrical conductivity ranging between 3 and $6 \mathrm{dS} \mathrm{m}^{-1}$ (Ayers and Westcot, 1999). However, the effect of salinity on plants may vary among species and even among genotypes of the same species (Ayers and Westcot, 1999; Sá et al., 2013).

Salt stress causes changes in several physiological and metabolic processes, inhibiting seedlings growth and crop production (Gupta and Huang, 2014). In addition to these limitations, salt stress initially causes stomatal closure and increased leaf temperature, which results in loss of growth, leaf expansion and quality of seedlings (Roy et al., 2014).

The most compromising effects of salinity on seedling production, specifically papaya, are reflected in inhibiting seed germination viability, generalized reduction of growth, loss of productive capacity and agriculture sustainability (Sá et al., 2013). In addition to these effects, reductions in absorption of some essential nutrients with negative changes in the nutritional aspects of plants are seen (Parés and Basso, 2013).

Organic compounds both in solid form such as organic matter (Silva et al., 2008), and in liquid form such as some biofertilizers produced with bovine manure, attenuate deleterious effects of irrigation water salinity during the formation of papaya seedlings 
(Mesquita et al., 2012). Biofertilizers, when applied to soil, stimulate growth, photosynthetic rate, stomatal conductance, and plant transpiration even under saline conditions (Mesquita et al., 2014).

This study aimed at evaluating the effects of irrigation with saline water and bovine biofertilizer during the formation of 'Golden' papaya seedlings and on soil salinity.

\section{MATERIALS AND METHODS}

The experiment was conducted from November 2014 to January 2015 in a fiberglass greenhouse located at Areia (658' S, 35 $41^{\circ}$ 'W; 575 m a.s.1.), Paraíba, Brazil. The climate is, according to the Köppen classification, As' semihumid tropical, with rainfall from March to July or August, and average annual rainfall of $1200 \mathrm{~mm}$. The average air temperature is set around $24{ }^{\circ} \mathrm{C}$ and relative humidity ranges from $75 \%$ in November to $87 \%$ in June and July.

The substrate consisted of $2 \mathrm{~L}$ soil material collected at 0-20 cm depth, classified as an Entisol according to the criteria of the Brazilian System of Soil Classification (EMBRAPA, 2013). Physical and chemical fertility characteristics (Donagema et al., 2011) and soil salinity by EC of the saturated soil extract (Richards, 1954) are shown in Table 1.

Treatments were distributed in randomized blocks with six replicates and six plants per plot, using a factorial arrangement $5 \times 2$ referring to irrigation water salinity levels $\left(0.5,1.0,2.0,3.0\right.$, and $\left.4.0 \mathrm{dS} \mathrm{m}^{-1}\right)$ in soil with and without common bovine biofertilizer. The EC of irrigation water was evaluated according to Rhoades et al. (2000) from the

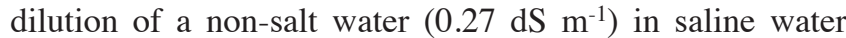
from a surface dam $\left(8.0 \mathrm{dS} \mathrm{m}^{-1}\right)$.

Bovine biofertilizer was obtained by anaerobic fermentation of a mixture of equal parts of non-salt water plus fresh manure of lactating cows (Silva et al., 2007). After fermentation, the organic raw material was diluted in water with a 1:1 ratio, evaluated as if it was irrigation water (Table 2 ), according to the method suggested by Richards (1954), and applied to the soil surface $2 \mathrm{~d}$ before sowing in $200 \mathrm{~mL}$, equivalent to $10 \%$ of the substrate volume.
Table 2. Results of chemical analysis of water used for irrigation and biofertilizer applied to the soil in liquid form.

\begin{tabular}{lcc}
\hline Variable & Water & Biofertilizer \\
\hline $\mathrm{pH}$ & 6.64 & 6.77 \\
$\mathrm{EC}$ at $25^{\circ} \mathrm{C}, \mathrm{dS} \mathrm{m}^{-1}$ & 0.45 & 3.11 \\
$\mathrm{Ca}^{2+}, \mathrm{mmol}_{\mathrm{c}} \mathrm{L}^{-1}$ & 1.21 & 5.25 \\
$\mathrm{Mg}^{2+}, \mathrm{mmol}_{\mathrm{c}} \mathrm{L}^{-1}$ & 0.78 & 6.29 \\
$\mathrm{Na}^{+}, \mathrm{mmol}_{\mathrm{c}} \mathrm{L}^{-1}$ & 2.38 & 9.21 \\
$\mathrm{~K}^{+}, \mathrm{mmol}_{\mathrm{c}} \mathrm{L}^{-1}$ & 0.12 & 10.47 \\
$\mathrm{SAR},\left(\mathrm{mmol}_{\mathrm{c}} \mathrm{L}^{-1}\right)^{0.5}$ & 2.39 & 3.83 \\
Classification & $\mathrm{C}_{1} \mathrm{~S}_{1}$ & $\mathrm{C}_{4} \mathrm{~S}_{1}$ \\
\hline
\end{tabular}

EC: Electrical conductivity; SAR: sodium adsorption ratio $=\mathrm{Na}^{+} /\left[\mathrm{Ca}^{2+}+\right.$ $\left.\left.\mathrm{Mg}^{2+}\right) / 2\right]^{0.5} ; \mathrm{C}_{1} \mathrm{~S}_{1}$ : water with low risk of salinization and soil sodification; $\mathrm{C}_{4} \mathrm{~S}_{1}$ : water with very high-risk of salinization and low-risk of soil sodification

The volume of soil material was $2 \mathrm{~L}$, which was wrapped in black polyethylene bags with total capacity of $2.5 \mathrm{~L}$, with holes in the bottom to allow part of the salt to lixiviate. Sowing was made with three 'Golden' papaya (Carica papaya L.) seeds at $1 \mathrm{~cm}$ depth in each experimental unit. The irrigation with each type of water, adopting a $10 \%$ leaching fraction to leach salts (Ayers and Westcot, 1999), was daily performed based on the process of weighing each replicate providing plant with the evapotranspirated water volume every $24 \mathrm{~h}$ to maintain soil moisture close to field capacity.

At $35 \mathrm{~d}$ after emergence (DAE), thinning was performed by keeping the strongest seedling in each polyethylene bag. At 90 DAE, plant height, stem diameter up to the neck, main root diameter and leaf area were obtained. Then, plants were harvested, separated in shoots and roots, and dried in an oven with air circulation at $65^{\circ} \mathrm{C}$ for $72 \mathrm{~h}$ until reaching constant mass. After drying, the material was weighed in a semianalytical scale to obtain dry mass of shoots and roots and, by the sum, total DM.

Plant height was measured from the neck to the insert of the last couple of leaves with a graduated scale. The diameter of the stem close to the soil and the main root $1 \mathrm{~cm}$ below the neck were measured with a digital caliper 6" (0.01-150 mm; Digimess, São Paulo, SP, Brazil) in mm; leaf area was quantified using photographic images taken with a digital camera (DSC W-55, Sony, Tokyo, Japan), 7.2 megapixels,

Table 1. Physical and chemical characterization of the soil in relation to fertility and salinity.

\begin{tabular}{|c|c|c|c|c|c|}
\hline \multicolumn{2}{|l|}{ Physical attributes } & \multicolumn{2}{|l|}{ Fertility } & \multicolumn{2}{|l|}{ Salinity } \\
\hline Soil density, $\mathrm{g} \mathrm{cm}^{-3}$ & 1.54 & $\mathrm{pH}$ in $\mathrm{H}_{2} \mathrm{O}(1: 2.5)$ & 6.59 & $\mathrm{pH}$ & 6.71 \\
\hline Particle density, $\mathrm{g} \mathrm{cm}^{-3}$ & 2.66 & $\mathrm{P}, \mathrm{mg} \mathrm{dm}^{-3}$ & 25.41 & $\mathrm{Ca}^{2+}, \mathrm{mmol}_{\mathrm{c}} \mathrm{L}^{-1}$ & 1.92 \\
\hline Total porosity, $\mathrm{m}^{3} \mathrm{~m}^{-3}$ & 0.42 & $\mathrm{~K}, \mathrm{mg} \mathrm{dm}^{-3}$ & 115.00 & $\mathrm{Mg}^{2+}, \mathrm{mmol}_{\mathrm{c}} \mathrm{L}^{-1}$ & 1.21 \\
\hline Sand, $\mathrm{g} \mathrm{kg}^{-1}$ & 858.00 & $\mathrm{Ca}^{2+}, \mathrm{cmol}_{\mathrm{c}} \mathrm{dm}^{-3}$ & 1.82 & $\mathrm{~K}^{+}, \mathrm{mmol}_{\mathrm{c}} \mathrm{L}^{-1}$ & 1.08 \\
\hline Silt, $\mathrm{g} \mathrm{kg}^{-1}$ & 59.00 & $\mathrm{Mg}^{2+}, \mathrm{cmol}_{\mathrm{c}} \mathrm{dm}^{-3}$ & 0.49 & $\mathrm{Na}^{+}, \mathrm{mmol}_{\mathrm{c}} \mathrm{L}^{-1}$ & 3.46 \\
\hline Clay, $\mathrm{g} \mathrm{kg}^{-1}$ & 83.00 & $\mathrm{Na}^{+}, \mathrm{cmol}_{\mathrm{c}} \mathrm{dm}^{-3}$ & 0.21 & $\mathrm{Cl}^{-}, \mathrm{mmol}_{\mathrm{c}} \mathrm{L}^{-1}$ & 5.17 \\
\hline CDW, $\mathrm{g} \mathrm{kg}^{-1}$ & 13.00 & $\mathrm{SB}, \mathrm{cmol}_{\mathrm{c}} \mathrm{dm}^{-3}$ & 2.81 & $\mathrm{CO}_{3}{ }^{2-}, \mathrm{mmol}_{\mathrm{c}} \mathrm{L}^{-1}$ & - \\
\hline $\mathrm{FD}, \%$ & 84.34 & $\mathrm{Al}^{3+}, \mathrm{cmol}_{\mathrm{c}} \mathrm{dm}^{-3}$ & 0.00 & $\mathrm{HCO}^{3-}, \mathrm{mmol}_{\mathrm{c}} \mathrm{L}^{-1}$ & 1.51 \\
\hline $\mathrm{DI}, \%$ & 15.66 & $\mathrm{H}^{+}+\mathrm{Al}^{3+}, \mathrm{cmol}_{\mathrm{c}} \mathrm{dm}^{-3}$ & 1.16 & $\mathrm{SO}_{4}{ }^{2-}, \mathrm{mmol}_{\mathrm{c}} \mathrm{L}^{-1}$ & 0.98 \\
\hline Moisture $-0.01 \mathrm{MPa}, \mathrm{g} \mathrm{kg}^{-1}$ & 10.84 & $\mathrm{CEC}, \mathrm{cmol}_{\mathrm{c}} \mathrm{dm}^{-3}$ & 3.97 & ECse, dS m ${ }^{-1}$ & 0.79 \\
\hline Moisture $-1.50 \mathrm{MPa}, \mathrm{g} \mathrm{kg}^{-1}$ & 4.54 & $\mathrm{~V}, \%$ & 70.78 & $\mathrm{SAR},\left(\mathrm{mmol}_{\mathrm{c}} \mathrm{L}^{-1}\right)^{0.5}$ & 2.75 \\
\hline Available water, $\mathrm{g} \mathrm{kg}^{-1}$ & 5.30 & $\mathrm{SOM}, \mathrm{g} \mathrm{dm}^{-3}$ & 11.31 & $\mathrm{ESP}, \%$ & 5.28 \\
\hline
\end{tabular}

CDW: Clay disperse in water; FD: flocculation degree [(Clay - CDW)Clay]100; DI: dispersion index (DI = $100-$ FD); P, K and Na ${ }^{+}=\mathrm{Mehlich} 1$ extractor; $\mathrm{Al}^{3+}, \mathrm{Ca}^{2+}, \mathrm{Mg}^{2+}=$ extractor $\mathrm{KCl} 1 \mathrm{M}$; SOM: soil organic matter by oxidation with potassium permanganate; $\mathrm{SB}$ : sum of exchangeable bases $\left(\mathrm{Na}{ }^{+}+\mathrm{K}^{+}+\mathrm{Ca}^{2+}\right.$ $\left.+\mathrm{Mg}^{2+}\right)$; CEC: cation exchange capacity $=\mathrm{SB}+\left(\mathrm{H}^{+}+\mathrm{Al}^{3+}\right)$; V: base saturation percentage $(100 \times \mathrm{SB} / \mathrm{CTC})$; ECse: electrical conductivity of the saturation extract; SAR: sodium adsorption ratio $=\mathrm{Na}^{+} /\left[\left(\mathrm{Ca}^{2+}+\mathrm{Mg}^{2+}\right) / 2\right]^{0.5} ;$ ESP: exchangeable sodium percentage $\left(100 \times \mathrm{Na}^{+} / \mathrm{CTC}\right)$. 
and processed by the Sigma Scan Pro 5.0 Demo software (Systat Software Inc., Chicago, Illinois, USA).

Immediately after plants collection, substrate samples were taken from each experimental unit to evaluate salt content based on ECse according to the methodological procedure described by Richards (1954).

Data were submitted to ANOVA by F test. The averages for the use of biofertilizers were compared by $\mathrm{F}$ test and irrigation water salinity levels were subjected to regression analysis using the statistical software SISVAR (Ferreira, 2011).

\section{RESULTS AND DISCUSSION}

The increase in irrigation water salinity from 0.5 to 4.0 $\mathrm{dS} \mathrm{m} \mathrm{m}^{-1}$ raised, within $90 \mathrm{DAE}$, soil's EC of the saturation extract (ECse) from 1.19 to $3.95 \mathrm{dS} \mathrm{m}^{-1}$ and from 1.23 to $3.63 \mathrm{dS} \mathrm{m} \mathrm{m}^{-1}$ in treatments with and without bovine biofertilizer, respectively (Figure 1). Despite the similarity between data under both conditions and the soil not reaching an ECse equal or greater than $4 \mathrm{dS} \mathrm{m}^{-1}$ (Richards, 1954), the increase in water salinity from 0.5 to $4.0 \mathrm{dS} \mathrm{m}^{-1}$ provided a $195.1 \%$ and $231.9 \%$ increase in soil salinity with and without organic inputs, respectively. These values express $66.2 \%$ and $55.7 \%$ increases in soil salinity for each unitary rise in water salinity.

Water salinity contributes at least with $50 \%$ for increased soil salinity (Ayers and Westcot, 1999). If a 10\% leaching blade had not been assumed, in treatments with a water saline content of $1,2,3$, and $4 \mathrm{dS} \mathrm{m}^{-1}$, the increase of salts in soil would have been greater. Cavalcante et al. (2010), evaluating seedling growth of the same crop under irrigation with saline water from a surface dam and with water enriched with $\mathrm{NaCl}$ and $\mathrm{Na}_{2} \mathrm{SO}_{4}$, with $0.4,2.0,4.0,6.0$, and $8.0 \mathrm{dS} \mathrm{m} \mathrm{m}^{-1} \mathrm{EC}$, without using the leaching fraction, observed that salinity reached $11.05,8.80$ and $7.56 \mathrm{dS} \mathrm{m}^{-1}$, respectively. Lower salinity levels indicates the importance of the $10 \%$ leaching fraction in addition to soil by the agriculture's restrictive water (Rhoades et al., 2000; Diniz et al., 2013), and provides greater plant growth even under salt stress.

The initial soil salinity expressed by ECse was 0.79 $\mathrm{dS} \mathrm{m}^{-1}$ (Table 1). Although it is a sandy soil with good

Figure 1. Soil electrical conductivity of saturated soil extract (ECse), irrigated with saline water, in soil with $(-)$ and without (- - ) bovine biofertilizer.

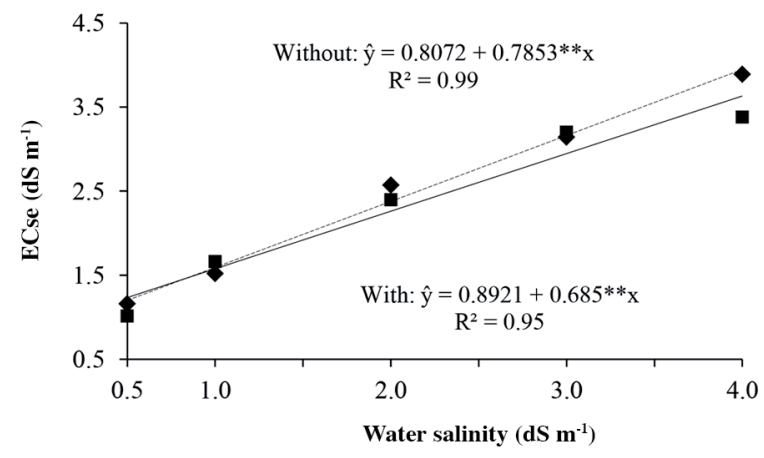

salt leaching ability and the adoption of leaching fraction, it appears that irrigation with $4 \mathrm{dS} \mathrm{m}^{-1}$ water, considered a severe restriction (Ayers and Westcot, 1999), raised the salt content of originally non-saline soil close to a typical saline level (Richards, 1954). Such situation may compromise both growth and quality of seedlings moderately tolerant to salts during cultivation, such as 'Golden' papaya seedlings (Ayers and Westcot, 1999).

The increase in water salinity from $0.5 \mathrm{dS} \mathrm{m} \mathrm{m}^{-1}$ to the estimated maximum values ranging from 1.46 and 2.13 $\mathrm{dS} \mathrm{m} \mathrm{m}^{-1}$ stimulated seedling height growth up to 11.42 and $18.72 \mathrm{~cm}$ in soil with and without bovine biofertilizer, respectively (Figure 2A). The addition of a biofertilizer inhibited the suppressive effect of salinity by providing a $45.8 \%$ more saline water, and overcame in $63.5 \%$ seedling height growth, compared to the same treatment without biofertilizer. However, irrigation with a water EC higher than the estimated maximum inhibited in 9.57 and 4.49 $\mathrm{cm}$ the growth of seedlings and caused $83.9 \%$ and $23.9 \%$ losses in height growth compared to plants irrigated with water of $4.0 \mathrm{dS} \mathrm{m}{ }^{-1}$, in treatments with and without bovine biofertilizer, respectively. The adverse effects of salinity on seedlings height growth in a same crop were also presented by Cavalcante et al. (2010) and Parés and Basso (2013).

The effects of water salinity and biofertilizer use in seedling stem growth were similar to those observed for seedling height (Figure 2). The stem diameters increased from 3.83 to $4.27 \mathrm{~mm}$ and from 5.04 to $6.16 \mathrm{~mm}$, corresponding to $11.5 \%$ and $22.2 \%$ increases between plants irrigated with water from 0.5 to $1.43 \mathrm{dS} \mathrm{m}^{-1}$ and from 0.5 to $2.48 \mathrm{dS} \mathrm{m}^{-1}$ in soil without and with bovine biofertilizer, respectively. On the other hand,

Figure 2. Height (A) and stem diameter (B) of papaya seedlings irrigated with saline water in soil with (-) and without (- - -) bovine biofertilizer.
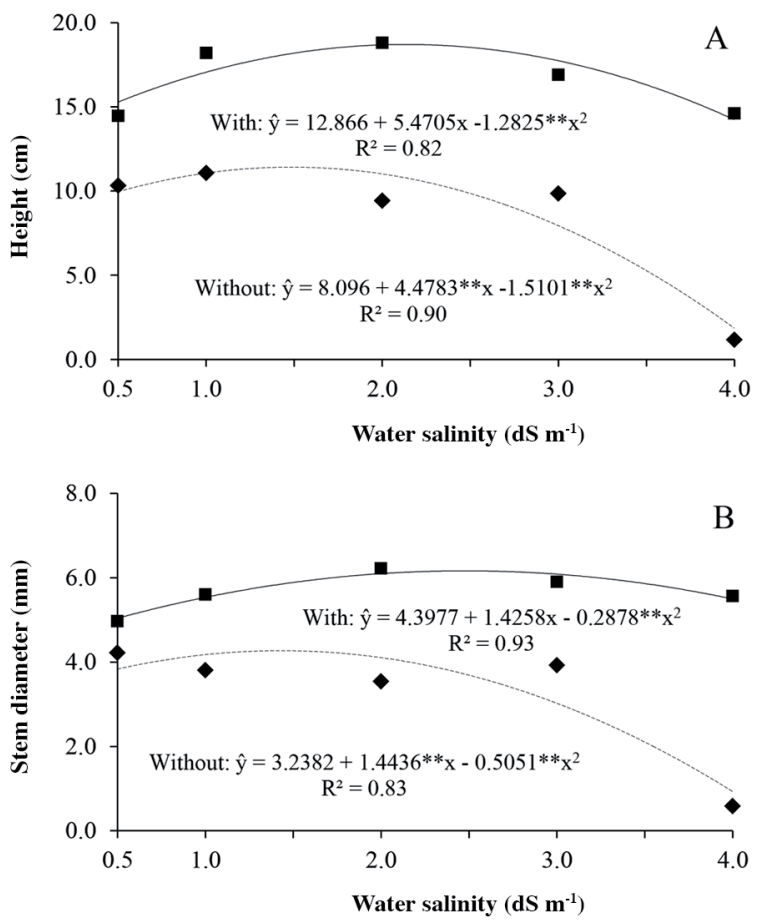
considering the same treatments, irrigation with saline water content higher than 1.43 and $2.48 \mathrm{dS} \mathrm{m}^{-1}$ inhibited stem growth until 0.93 and $5.51 \mathrm{~mm}$, reflecting $78.2 \%$ and $10.6 \%$ losses in plant growth irrigated with $4.0 \mathrm{dS} \mathrm{m}^{-1}$ water (Figure 2B). The observed decreased values are corroborated by Sá et al. (2013), who observed that water salinity ranging from 1.2 to $4.8 \mathrm{dS} \mathrm{m}^{-1}$ damaged the diameter of papaya seedlings. This is given by the fact that salt stress leads to reduced net photosynthesis rate and stomatal conductance, consequently diminishing $\mathrm{CO}_{2}$ assimilation rate, compromising plant growth (Fernández-García et al., 2014).

The highest values of seedlings in treatments with biofertilizers are responses from humic substances in organic compounds, which provides greater osmotic adjustments between root and soil solution. This fact results in decreased intensity of salt toxic effects on growth (Aydin et al., 2012) and increased absorption efficiency of water and essential nutrients (Morard et al., 2011), stimulating plants to grow (Dordas et al., 2008; Matsi et al., 2015).

Leaf area of papaya seedlings in soil without organic inputs suffered a linear reduction of $28.94 \mathrm{~cm}^{2}$ per unitary increase in water salinity, with decreases from $119.78 \mathrm{~cm}^{2}$ in non-saline water to $18.49 \mathrm{~cm}^{2}$ in $4.0 \mathrm{dS} \mathrm{m} \mathrm{m}^{-1}$ water. This corresponds to an $84.56 \%$ loss among seedlings irrigated with water with lesser and higher salt concentrations and $24.16 \%$ for each unitary increase in irrigation water EC (Figure 3). These results corroborate results found by Silva et al. (2008), who observed a reduction both in the number of leaves and in leaf area in guava (Psidium guajava L.) plants subjected to salinity treatments. According to Taiz and Zeiger (2013), in general, when plants are subjected to salt stress, including papaya (Sá et al., 2013), reduced leaf area is displayed as a defense mechanism to losses of gas exchange due to $\mathrm{CO}_{2}$ absorption processes and water transpiration. This mechanism contributes to the gradual adjustment of osmotic salts in plants. Other drawback of salinity is the toxic action of salt excesses in irrigation water, which promotes abscission and leaf senescence, with the consequent reduction in emission of leaves and leaf area of plants (Roy et al., 2014).

In soils with the addition of biofertilizer, the increase in water salinity from 0.5 up to $1.63 \mathrm{dS} \mathrm{m}^{-1}$ promoted leaf expansion from 139.6 to $152.1 \mathrm{~cm}^{2}$ per seedling, with

Figure 3. Leaf area of papaya seedlings irrigated with saline water in soil with (-) and without (- -) bovine biofertilizer.

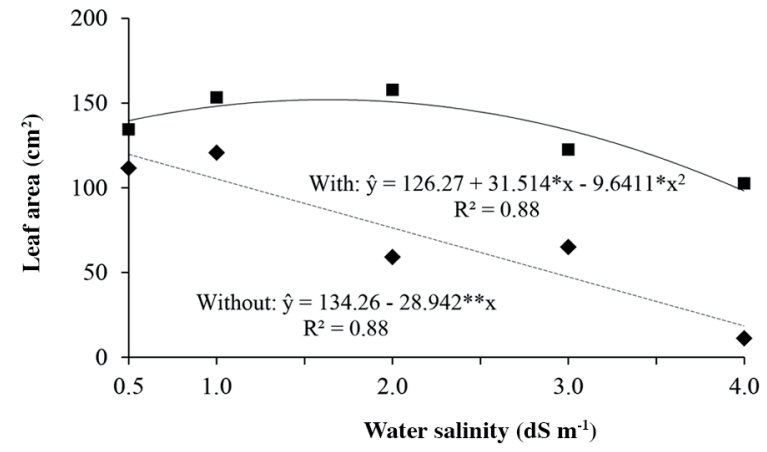

an $8.9 \%$ increase. However, irrigation with saline water inhibited seedling leaf growth to the lowest value $\left(98.1 \mathrm{~cm}^{2}\right)$, with a $35.5 \%$ loss among seedlings irrigated with 1.63 and $4.0 \mathrm{dS} \mathrm{m}{ }^{-1}$ water. Similar results were obtained by Mesquita et al. (2012) who concluded that chemically enriched biofertilizers (fresh bovine manure plus water, gypsum, molasses and milk), under anaerobic fermentation, mitigated the degenerative effects of irrigation water salinity for papaya seedlings. These data are in accordance with Dordas et al. (2008), who reported that application of liquid bovine manure promoted increases in leaf area in corn plants.

Papaya's root growth, evaluated by the diameter of the main root, was diminished from 0.22 to $0.12 \mathrm{~mm}$, with $45.5 \%$ of losses among plants irrigated with 0.5 and $4.0 \mathrm{dS}$ $\mathrm{m}^{-1}$ water and $13 \%$ per unitary increase in water salinity (Figure 4A). This behavior is commonly observed in the majority of plants that are sensitive, moderately sensitive and moderately tolerant to salt (Ayers and Westcot, 1999), such as the 'Golden' papaya (Mesquita et al., 2012). When considering that this tolerance occurs by the direct contact of the root system with the environment under salt stress, the most damaging ions to plants are $\mathrm{Na}^{+}$and $\mathrm{Cl}^{-}$(Munns and Tester, 2008). The accumulation of these ions in plant tissues causes nutritional imbalances, with losses in the absorption of other elements such as $\mathrm{K}^{+}$and $\mathrm{Ca}^{2+}$, which are essential to growth, development and osmoregulation (Silva et al., 2010; Fernández-García et al., 2014).

Increased diameter of the main root from 0.12 to 0.23 $\mathrm{mm}$ indicates a positive action of the biofertilizer in cell division and root growth (Figure 4B). Cavalcante et al. (2011) and Mesquita et al. (2012) also reported a similar

Figure 4. Main root diameter of papaya seedlings irrigated with saline water (A), in soil without and with bovine biofertilizer (B).
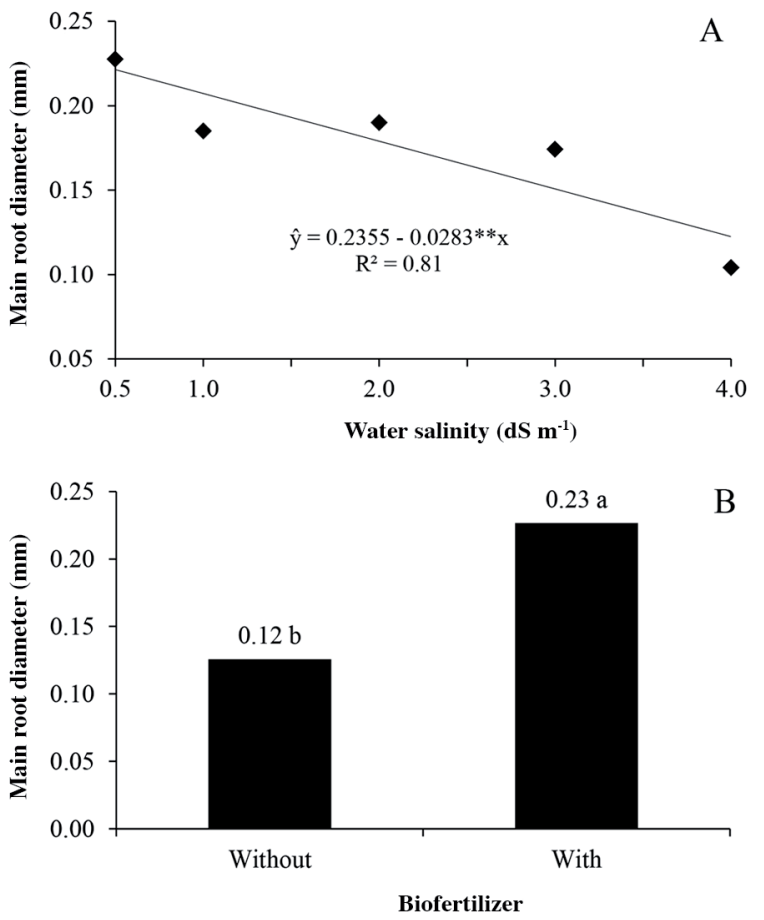
behavior observing that humic substances (humin, fulvic acids and humic acids; Humitec, Tradecorp, Madrid, Spain) and chemically enriched biofertilizer stimulated the growth of shoots and roots of 'Formosa' and 'Sunrise Solo' papaya. The attenuators effects of organic inputs occurs due to the presence of humic substances in its composition that promotes enhancements in physical, chemical, and biological soil attributes, which are reflected in improved root architecture, formation of new roots and greater absorption of water and nutrients by plants (Asik et al., 2009; Canellas and Olivares, 2014).

The production of seedling shoot dry biomass in soils without organic inputs decreased with the intensification of salt water content from 0.25 to $0.04 \mathrm{~g}$, with an $84 \%$ loss of seedlings irrigated with 0.5 and $4.0 \mathrm{dS} \mathrm{m}^{-1}$ water, and a $24 \%$ per unitary increase of water salinity (Figure 5). Similar results were shown by Cavalcante et al. (2010) and Parés and Basso (2013) with 'Sunrise Solo' papaya irrigated with saline water from 0.5 up to 4.0 and from 0.001 up to $8.0 \mathrm{dS} \mathrm{m}^{-1}$, respectively. In soils containing biofertilizer, the increase in water salinity from 0.5 to the estimated maximum value of $1.96 \mathrm{dS} \mathrm{m}^{-1}$ increased the production of seedling dry biomass from 0.47 to $0.61 \mathrm{~g}$, promoting a $29.8 \%$ increase and enabling the use of more salt in water for seedling formation. These results confirm that salt stress, despite inhibiting plants growth (Sá et al., 2013), reduces its effects by applying organic compounds to the soil, such as bovine manure (Silva et al., 2008).

Despite the fact that salt stress reduces both transpiration and stomatal conductance in the vast majority of crop plants, as observed by Silva et al. $(2010 ; 2014)$ for jatropha plants and citrus, respectively, with losses in $\mathrm{CO}_{2}$ influx in the substomatal cavity and in the photosynthetic process (Taiz and Zeiger, 2013), the use of bovine biofertilizer attenuates part of such damages to the metabolic process. Attenuation is the input's response to increased stomatal conductance, net photosynthesis rate and transpiration, as found by Mesquita et al. (2014) with corn under biofertilizer and saline water irrigation. It expresses a positive effect of organic input in decreasing the deleterious effects of salts to plants, as observed for papaya seedlings.

Figure 5. Dry matter of the aerial part of papaya seedlings irrigated with saline water, in soil with (-) and without (- - -) bovine biofertilizer.

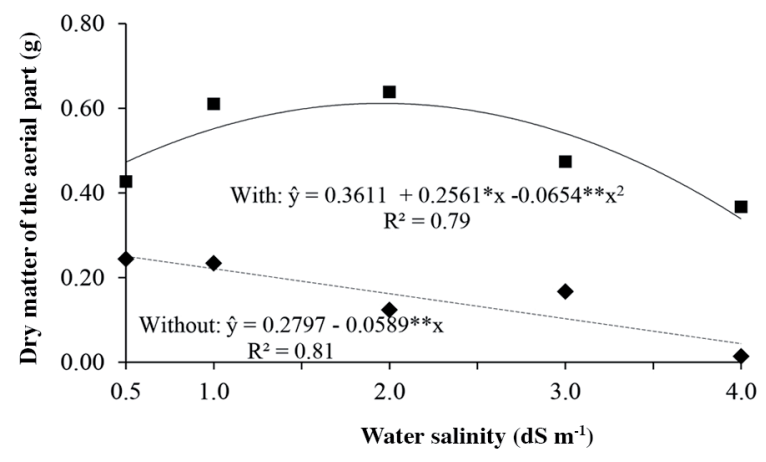

The increase in water salt concentration linearly inhibited seedling root dry biomass to a level of $0.0445 \mathrm{~g}$ per unitary increase in EC (Figure 6A), and it increased total DM (aerial parts plus roots) with the intensification of water salt content from 0.5 to $1.0 \mathrm{dS} \mathrm{m}^{-1}$ (Figure 7A). Although root values are

Figure 6. Root dry matter of papaya seedlings irrigated with saline water (A) in soil with and without bovine biofertilizer $(B)$.
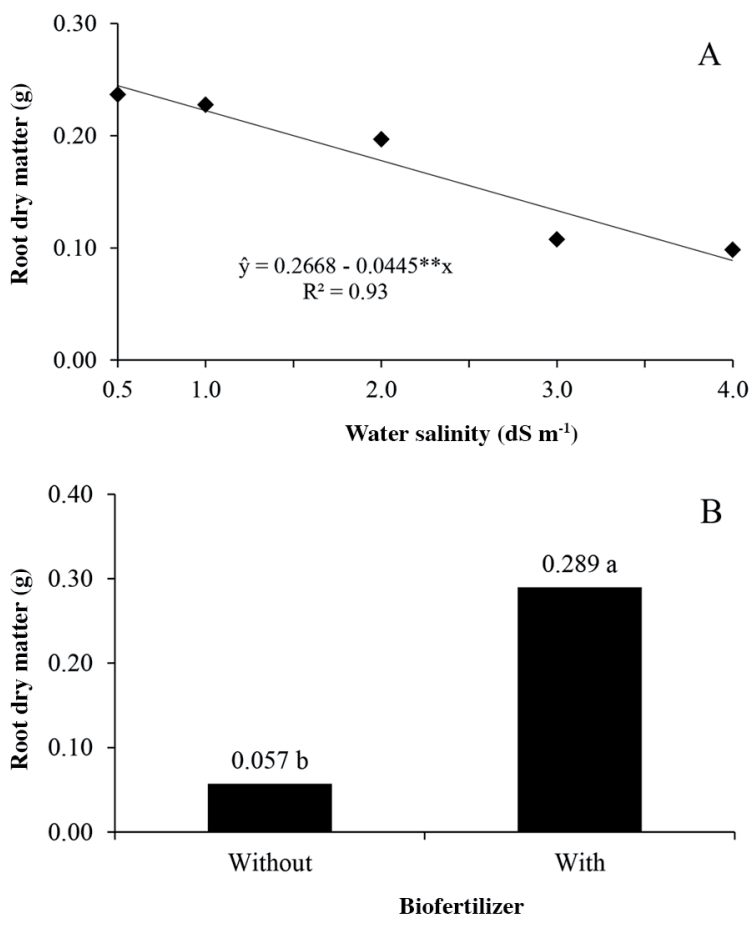

Figure 7. Total dry matter of papaya seedlings irrigated with saline water (A), in soil with (-) and without (- - -) bovine biofertilizer (B).
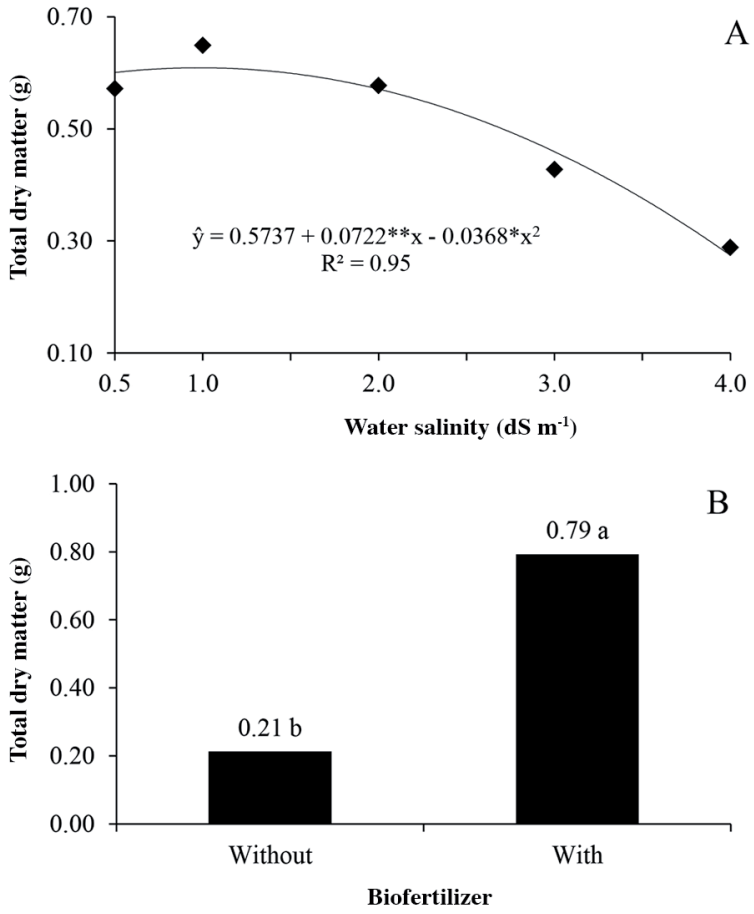
reduced from 0.244 to $0.089 \mathrm{~g}$, with $63.5 \%$ losses of seedlings irrigated with water with lesser and higher EC and $18.1 \%$ per unitary increase of water salinity (Figure 6A), the values of total DM increased from 0.601 to $0.609 \mathrm{~g}$, expressing, even if modestly, a $1.3 \%$ increase in seedling total DM (Figure 7A). Similar situations were observed by Cavalcante et al. (2010) and Sá et al. (2013), concluding that the irrigation of papaya 'Golden' seedlings with increasing salinity, caused reductions in the production of roots and total DM of papaya.

For Ayers and Westcot (1999) and Munns and Tester (2008), depending on the salinity level in the water, decreases in soil osmotic potential act negatively on physiological processes by reducing water and nutrients uptake by roots, inhibiting meristematic activity and cell elongation, causing losses in plant growth in general. Salinity induces oxidative damage to various cellular components such as proteins, lipids and DNA, impairing vital cellular functions of plants (Gupta and Huang, 2014).

Bovine biofertilizer provided greater production of root dry biomass, from 0.057 to $0.289 \mathrm{~g}$ (Figure 6B) and from 0.210 to $0.790 \mathrm{~g}$ in total dry biomass (Figure $7 \mathrm{~B}$ ). This performance indicates $407 \%$ and $276.2 \%$ of gains provided by the application of bovine biofertilizer on seedling root and total dry biomass of papaya 'Golden'. These results are consistent with those observed by Mesquita et al. (2012) for papaya seedlings with the application of biofertilizer enriched with gypsum, sugarcane molasses and cow milk. Bovine manure, besides being a source of nutrients to plants, is a source of microorganisms (Marrocos et al., 2012). It contributes to soil physical characteristics and chemical content (Matsi et al., 2015; Schlegel et al., 2015), stimulating root growth and the absorption of water and nutrients by plants.

Even do not eliminate adverse effects of salinity to plants, bovine biofertilizers enables the use of water with a moderate restriction by salts (conductivity around $1.5 \mathrm{dS} \mathrm{m} \mathrm{m}^{-1}$ ) in papaya seedlings production. Currently, reduced availability of water without salt restriction to food production is a global concern and demands technologies to mitigate salts problem. Although the literature emphasize that papaya is moderately tolerant to salinity, which would not harm its growth in environments with ECse of soil between 3 and 6 $\mathrm{dS} \mathrm{m}{ }^{-1}$ (Ayers and Westcot, 1999), it was found that, even though soil salinity has not reached the maximum value of the crop (Figure 1), plants suffered decreases in all growth variables, proving that 'Golden' in the seedling stage did not behave as moderately tolerant.

Considering the results observed for the variables: height, stem diameter, leaf area and shoot DM, it appears that, although not totally eliminating the deleterious effects of salinity on seedlings' growth, the application of a biofertilizer in the soil allows the use of water with a higher salt content without significant losses in plants growth. These results were also observed by Mesquita et al. (2012), who evaluated the use of chemically enriched biofertilizers with gypsum, cow's milk and sugarcane molasses on the growth of 'Golden' papaya seedlings irrigated with saline water.

\section{CONCLUSIONS}

The increase in irrigation water salinity increased soil salinity and inhibited papaya seedlings growth, but with less severity in the treatments with bovine biofertilizers.

Bovine biofertilizer, although does not eliminate the adverse effects of salinity to plants, stimulates seedlings growth. The application of organic inputs to the soil made the use of water with up to $1.63 \mathrm{dS} \mathrm{m}^{-1}$ possible, without compromising plants growth. These results show that the application of organic amendments can be an alternative for the production of papaya seedling in nurseries.

Among the variables analyzed, leaf area was the most sensitive to salt stress due to its greater reduction with increasing salinity.

\section{REFERENCES}

Anuário Brasileiro de Fruticultura. 2015. 104 p. Editora Gazeta, Santa Cruz do Sul, Rio Grande do Sul, Brasil.

Asik, B.B., M.A. Turan, H. Celik, and V.A. Katkat. 2009. Effects of humic substances on plant growth and mineral nutrients uptake of wheat (Triticum durum cv. Salihli) under conditions of salinity. Asian Journal of Crop Science 1:87-95. doi:10.3923/ ajcs.2009.87.95.

Aydin, A., C. Kant, and M. Turan. 2012. Humic acid application alleviate salinity stress of bean (Phaseolus vulgaris L.) plants decreasing membrane leakage. African Journal of Agricultural Research 7:1073-1086. doi:10.5897/AJAR10.274.

Ayers, R.S., e D.W. Westcot. 1999. A qualidade da água na agricultura. In Gheyi, H.R., J.F. Medeiros, and F.A.V. Damasceno (trad.) Irrigação e Drenagem 29. 153 p. Universidade Federal da Paraíba (UFPB), Campina Grande, Paraíba, Brasil.

Canellas, L.P, and F.L. Olivares. 2014. Physiological responses to humic substances as plant growth promoter. Chemical and Biological Technologies in Agriculture 1:1-11. doi:10.1186/21965641-1-3.

Cavalcante, L.F., J.C. Cordeiro, J.A.M. Nascimento, I.H.L. Cavalcante, e T.J. Dias. 2010. Fontes e níveis da salinidade da água na formação de mudas de mamoeiro cv. sunrise solo. Semina: Ciências Agrárias 31:1281-1290. doi:10.5433/16790359.2010v31n4Sup1p1281.

Cavalcante, I.H.L., R.R.S. Silva, F.G. Albano, F.N. Lima, and A.S. Marques. 2011. Foliar spray of humic substances on seedling production of Papaya (Pawpaw). Journal of Agronomy 10:118122. doi:10.3923/ja.2011.118.122.

Diniz, B.L.M.T, L.F. Cavalcante, F.O. Mesquita, A.J. Lima Neto, J.C. Nunes, e M.A. Diniz Neto. 2013. Crescimento inicial e consumo hídrico de nim submetido ao estresse salino e biofertilizante bovino. Revista Brasileira de Ciências Agrárias 8:470-475. doi:10.5039/agraria.v8i3a2613.

Donagema, G.K., D.V.B. Campos, S.B. Calderano, W.G. Teixeira, e J.H.M. Viana. 2011. Manual de métodos de análise de solo. 230 p. $2^{\text {nd }}$ ed. Embrapa Solos, Rio de Janeiro, Brasil.

Dordas, C.A., A.S. Lithourgidis, T. Matsi, and N. Barbayiannis. 2008. Application of liquid cattle manure and inorganic fertilizers affect dry matter, nitrogen accumulation, and partitioning in maize. Nutrient Cycling in Agroecosystems 80:283-296. doi:10.1007/s10705-007-9143-1.

EMBRAPA. 2013. Sistema brasileiro de classificação de solos. 353 p. $3^{\text {rd }}$ ed. Embrapa Solos, Brasília, Brasil. 
Fernández-García, N., E. Olmos, E. Bardisi, J. García-De La Garma, C. López-Berenguer, and J.S. Rubio-Asensio. 2014. Intrinsic water use efficiency controls the adaptation to high salinity in a semi-arid adapted plant, henna (Lawsonia inermis L.) Journal of Plant Physiology 171:64-75. doi:10.1016/j.jplph.2013.11.004.

Ferreira, D.F. 2011. Sisvar: a computer statistical analysis system. Ciência e Agrotecnologia 35:1039-1042. doi:10.1590/S141370542011000600001.

Gupta, B., and B. Huang. 2014. Mechanism of salinity tolerance in plants: Physiological, biochemical, and molecular characterization. International Journal of Genomics 2014:1-18. doi: $10.1155 / 2014 / 701596$.

Marrocos, S.T.P., J. Novo Junior,L.C. Grangeiro, M.M.Q.Ambrosio, e A.P.A. Cunha. 2012. Composição química e microbiológica de biofertilizantes em diferentes tempos de decomposição. Revista Caatinga 25:34-43.

Matsi, T.H., A.S. Lithourgidis, and N. Barbayiannis. 2015. Effect of liquid cattle manure on soil chemical properties and corn growth in Northern Greece. Experimental Agriculture 51:435-450. doi: $10.1017 /$ S0014479714000404.

Mesquita, F.O., R.M. Rodrigues, R.F. Medeiros, L.F. Cavalcante, e R.O. Batista. 2012. Crescimento inicial de Carica papaya sob irrigação com águas salinas em solo com biofertilizante bovino. Semina: Ciências Agrárias 33:2689-2704. doi:10.5433/16790359.2012v33n6Supl1p2689.

Mesquita, S.B.S., J.A. Silva, R.S. Costa, M.W.N. Santos, C.F. Lacerda, A.V. Amorim, et al. 2014. Gas exchange and growth of medicinal plant subjected to salinity and application of biofertilizers. American Journal of Plant Sciences 5:2520-2527. doi:10.4236/ajps.2014.516266.

Morard, P., B. Eyheraguibel, M. Morard, and J. Silvestre. 2011. Direct effects of humic-like substance on growth, water, and mineral nutrition of various species. Journal of Plant Nutrition 34:46-59. doi:10.1080/01904167.2011.531358.

Munns, R., and M. Tester. 2008. Mechanisms of salinity tolerance. Annual Review of Plant Biology 59:651-681. doi:10.1146/ annurev.arplant.59.032607.092911.

Parés, J., y C. Basso. 2013. Efecto del cloruro de sodio sobre el crecimiento y estado nutricional de plantas de papaya. Bioagro 25:109-116.

Rhoades, J.D., A. Kandiah, e A.M. Mashali. 2000. Uso de águas salinas para produção agrícola. 117 p. Universidade Federal da Paraíba (UFPB), Campina Grande, Paraíba, Brasil.
Richards, L.A. 1954. Diagnóstico y rehabilitación de suelos salinos y sódicos. Manual de Agricultura 60.172 p. USDA, Washington D.C., USA.

Roy, S.J., S. Negrão, and M. Tester. 2014. Salt resistant crop plants. Current Opinion in Biotechnology 26:115-124. doi:10.1016/j. copbio.2013.12.004.

Sá, F.V.S., M.E.B. Brito, A.S. Melo, P. Antônio Neto, P.D. Fernandes, e I.B. Ferreira. 2013. Produção de mudas de mamoeiro irrigadas com água salina. Revista Brasileira de Engenharia Agrícola e Ambiental 17:1047-1054. doi:10.1590/ S1415-43662013001000004.

Santos, F.S.S., T.V.A. Viana, B.M.Azevedo, C.W. Oliveira, e A.E.C. Sousa. 2008. Efeito de diferentes lâminas de irrigação na cultura do mamão. Engenharia Agrícola 28:673-680. doi:10.1590/ S0100-69162008000400007.

Schlegel, A.J., Y. Assefa, H.D. Bond, S.M. Wetter, and L.R. Stone. 2015. Soil physicochemical properties after 10 years of animal waste application. Soil Science Society of America Journal 79:711-719. doi:10.2136/sssaj2014.11.0461.

Serrano, L.A.L., e L.F. Cattaneo. 2010. O cultivo do mamoeiro no Brasil. Revista Brasileira de Fruticultura 32:657-659. doi:10.1590/S0100-29452010000300001.

Silva, L.A., M.E.B. Brito, F.V.S. Sá, R.C.L. Moreira, W.S. Soares Filho, e P.D. Fernandes. 2014. Mecanismos fisiológicos em híbridos de citros sob estresse salino em cultivo hidropônico. Revista Brasileira de Engenharia Agrícola e Ambiental 18:1-7.

Silva, A.B.F., P.D. Fernandes, H.R. Gheyi, and F.F. Blanco. 2008. Growth and yield of guava irrigated with saline water and addition of farmyard manure. Revista Brasileira de Ciências Agrárias 3:354-359.

Silva, A.F., J.M. Pinto, C.R.R.S. França, S.C. Fernandes, T.C.A. Gomes, M.S.L. Silva, et al. 2007. Preparo e uso de biofertilizantes líquidos. 4 p. Comunicado Técnico 130. Embrapa Semi-Árido, Ministério da Agricultura, Pecuária e Abastecimento, Petrolina, Pernambuco, Brasil.

Silva, E.N., R.V. Ribeiro, S.L. Ferreira-Silva, R.A. Viégas, and J.A.G. Silveira. 2010. Comparative effects of salinity and water stress on photosynthesis, water relations and growth of Jatropha curcas plants. Journal of Arid Environments 74:1130-1137. doi:10.1016/j.jaridenv.2010.05.036.

Taiz, L., e E. Zeiger. 2013. Fisiologia vegetal. 918 p. $5^{\text {th }}$ ed. Artmed, Porto Alegre, Rio Grande do Sul, Brasil. 